\title{
Student Teacher Preparedness for Teaching Practice at Faculty of Agriculture and Consumer Sciences in The University of Eswatini
}

\author{
Alfred F. Tsikati \\ Lecturer, Department of Agricultural Education and Extension \\ University of Eswatini, Luyengo, Manzini, Eswatini \\ Sifiso Nsingwane \\ Agriculture Teacher, Agriculture Department, \\ Nsingweni High school. Manzini, Eswatini
}

\begin{abstract}
Student preparation in teacher education is a crucial factor for teaching practice. Unfortunately, research conducted on student teacher preparedness for teaching practice at the Faculty of Agriculture and Consumer Sciences lacking. Thus, the purpose of the study was to describe student teacher preparedness for teaching practice at the Faculty of Agriculture and Consumer Sciences at the University of Eswatini. This was a correlational study employing self-administered questionnaires in data collection. A census of 80 fourth year Agricultural Education and Consumer Sciences Education students was used. Post hoc inter-item reliability using Cronbach's Alpha revealed that the questionnaire was $\mathbf{7 4}$ reliable. Three experts from the Department of Agricultural Education and Extension validated the instrument. Data were analyzed using descriptive and correlational statistics. Results revealed that student teachers were prepared for teaching practice on the following: student discipline; setting test and exam questions, student assessment practices; effective use of teaching aids; classroom management; understanding student behaviour; and Information and Communication Technology. The study concluded that the student teachers were prepared for teaching practice and there was congruence between the preparation and the teaching practice. The Faculty of Agriculture and Consumer Sciences should match the needs of students and those of the teaching practice school.
\end{abstract}

Keywords: micro-peer teaching, pedagogy, student teacher, student teacher preparation, teacher education, teaching practice, teaching practicum

\section{INTRODUCTION}

Ronfeldt and Reininger [1] consider teaching practice as a "centerpiece of teacher preparation worldwide" (p.1104). Mannathoko [2]) argued that the purpose for teaching practice is to introduce prospective teachers to teaching and its routines under the guidance of qualified professionals to develop skills, attitudes and competences in the profession. The key focus areas in the exercise is fostering links between educational theory and practice, developing student teacher's ability and developing the ability to select and use appropriate teaching resources. Bill and Melinda Gate Foundation [3] stated that teaching practice is a learning experience that allows a student teacher to identify his strengths and weaknesses, and use both of them to the best advantage of his job. Thus, Goethals and Howard [4] viewed student teaching as the most challenging, rewarding, and critical stage of teacher education. Kiggundu and Nayimuli [5] on the other hand concluded that teaching practice can make or break the student teacher. 
One of the most crucial factors in the teaching practice situation for the student teacher is preparation [6]. Teaching practice stage is considered crucial but can be much easier if a student teacher has been well prepared [7]. Farrant [7] further concluded that teaching practice is in a sense experiential learning and as such, requires thorough preparation beforehand if it is to be beneficial to the aspirant. This preparation starts off with observation of a qualified teacher teaching. Teaching practice provides a platform for the student teachers to test what they have been exposed to during the preparation stage [8]). The student teacher preparation provides a wide variety of experiences that focus on content knowledge, instructional objectives, lesson planning, state and national standards, classroom management, teaching styles, instructional effectiveness, authentic assessments and providing an teachinglearning atmosphere that is emotionally and physically safe [9].

The ultimate goal teaching practice is to enable all beginning teachers to show mastery of specific competencies acquired during the pre-service stage [8]. Student teachers during teaching practice have an opportunity to put into practice all that has been taught to them during their skills classes, methods classes, observation experiences, physical education pedagogy classes and practicum experiences. It is the student teaching experience that serves as a transition from the confines of the college classroom into the reality-based professional world of a school-based gymnasium [9].

According to Farrant [7] preparing of student teachers for teaching practice should include: (i) setting aims and objectives purposefully, (ii) selecting appropriate content, (iii) deciding on the best method of presentation, and (iv) writing actual lesson notes. Bhargava [6] argued that provision of inadequate preparatory time to student teachers may result in difficulties in translating theoretical ideas into practical shape. A study by Heeralal and Bayaga [10] examining pre- service teachers training suggested that education faculties need to pay attention to flexibility in (i) time of course participation (ii) content of teaching practice (iii) instructional approaches and learning and (iv) course delivery and logistics.

Past research noted that a good student teacher should possess the following personal characteristics: (i) a positive self-image (ii) willing to accept others as well as self (iii) identifying in a positive way with others, and (iv) being well informed [11]. Similarly, Brownell, Ross, Colon and McCallum [12] identified connections between carefully planned coursework and field work (e.g. teaching practice); the use of varied strategies by teacher educators; coursework and field work that emphasise the needs of a diverse student population; teacher education that occurs within a collaborative professional community; a heavy emphasis on subject matter pedagogy; a clear vision of high quality teaching pervasive throughout the programme, and use of active pedagogy by teacher educators as general characteristics in highly effective teacher education programmes.

Haigh [13] argued that "teacher preparation institutions have the responsibility of providing prospective teachers with the skills necessary to meet the intellectual, social and personal needs of diverse learners" (p. 694). Bezzina and Madelinska-Michalak [8] recommended that student teachers should be equipped on lesson planning implementation skills, classroom management and nurturing professional and personal qualities. Cubukcu [16] reported that student teachers need to be prepared during micro-teaching on the following areas: (i) close connection between the course materials and practical application in real classroom; (ii) adequate micro-peer teaching; and (iii) individual presentations rather than group work. Pamela and Grossman (1990)[14] argued that professional preparation, such as methods, courses and fieldwork, are best in equipping teachers to work with a diverse student population. 
Pedagogical challenges facing student teachers during teaching practice can also reveal areas where the student teachers need to be assisted during the preparation stage for teaching practice. Bhargava [6] identified lesson planning, classroom management, time management and assessment and awarding of marks as some of the challenges student teachers encounter during teaching practice. Leach [15] was concerned about ability of student teachers in recognising learners' social and emotional needs, inappropriateness of some curriculum material for certain students, being fair to pupils and tailoring content to individual students during teaching practice practicum [15]. Cubukcu [16] found that student teachers need to be assisted on management of learners, English Language competence and lesson preparation. A clear understanding of these challenges implies that teacher educators should assist the student teachers as they embark on the teaching practice.

Perceived adequacy of skills and abilities, expectations about the workforce, teaching selfefficacy and attribution style are prerequisite variables in understanding the transition of student teachers from preparation for teaching practice to the actual teaching practice [17]. Firstly, individuals entering any profession should possess the required skills and abilities appropriate to the profession and to which universities are expected to make an important contribution [17]. Similarly, student teachers should possess the required skills and abilities as they undertake teaching practice. Surprisingly, Graham and McKenzie [18] reported that some students are not meeting the requirements of the workplace. Thus, Graham and McKenzie [18] argue that the university education should be designed to closely mimic the standards and procedures of work required by the workplace, as well as to equip students with the skills and knowledge valued by employers. Secondly, student teacher perceptions formed may influence their performance during teaching practice $[19,20,21]$. A student teacher may form unrealistic expectations regarding an array of factors such as workplace rewards, the degree of difficulty and nature of the work they will be doing, their likely workload and time pressures and the social structure or culture of the organisation.

Thirdly, the move of student teachers from a training institution to teaching practice may also be influenced by self-efficacy contribution [17]. Self-efficacy may influence how an individual will adjust to this transition. Self-efficacy influences whether an individual will initiate, persevere and succeed at a given task during the teaching practice, which is linked directly to the individual's personal experiences during the preparatory stage for the teaching practice. High teaching self-efficacy is likened to positive gains in teacher performance, student learning outcomes, the selection of learning activities, responses to student attempts, selection and use of classroom management techniques, responses to difficult students, stress management and job satisfaction[22, 23]. Individuals with a high sense of teaching efficacy are more likely to respond to the experience of 'reality shock' in an adaptive way. Lastly, the congruence between the training received by a student teacher and teaching practice is influenced by the attribution style contribution [17]. Personal experiences are likely to influence the student teacher's selfefficacy. Personal experience of success may contribute positively while a personal experience of failure may contribute negatively on the self-efficacy of the student teacher during teaching practice. Reports exist that teachers are likely to be attributing their own performance and effectiveness in the classroom to personality characteristics [24].

The Department of Agricultural Education and Extension at the University of Eswatini prepares student teachers for teaching practice technically and pedagogically. Technically, the student teachers take courses from the following departments: Agricultural Economics and Management; Animal Science; Agricultural Bio-systems and Engineering; Crop Production; and Horticulture. Pedagogically, the student teachers take courses from the Department of Agricultural Education and Extension. These courses are taken at Level I (Semester 1 and 2) 
and Level II (Semester 3 and 4). However, this study will focus only on the professional preparation of the student teachers for teaching practice.

The student teachers do their teaching practice during the fifth semester for a period of 12 weeks, an equivalence of the first Term in the education system of Eswatini. The overall objective of the teaching practice exercise at the University of Eswatini is to assist the student teachers combine philosophies of education with knowledge of today's society in forming professional beliefs [25].

Research on teaching practice conducted at the University of Eswatini includes the following among others: factors contributing to effective student teacher supervision in the Faculty of Agriculture and Consumer Sciences [26]; student teachers' experiences during teaching practice [27, 28]; student teachers' supervision experiences from cooperating teachers [29]; challenges faced by student teachers during teaching practice $[30 ; 31]$ and effectiveness of teaching practice on the performance of teachers [32]. No study has been conducted on congruence between the student teacher preparation and the teaching practice, yet, incongruence implies that student may have challenges in coping with teaching practice and later the teaching profession.

Therefore, the study sought to determine student teacher preparedness for teaching practice at Faculty of Agriculture and Consumer Sciences in the University of Eswatini. The objectives of the paper were to: (i) identify the student teacher training needs prior to preparation for teaching practice; (ii) describe the preparedness of students towards teaching practice; and (iii) describe the relationship between preparedness of students and their demographic characteristic and perceptions.

\section{THEORETICAL / CONCEPTUAL FRAMEWORK}

This study was framed by the Person-Environment Fit Theory and Social Learning Theory. The Person-Environment Fit Theory was postulated by Holland in 1985 [33]. Person-Environment Fit Theory is defined as the compatibility between individuals and their environment. The theory asserts that people have the freedom to choose their goals, activities, and relationships, they may regularly ask themselves whether their environment (opportunities, demands, social context) offers what they wish for. The theory is built on three basic principles [34]. Firstly, the fit theory postulates that fit is a more powerful predictor of individual outcomes e.g., job satisfaction [35]. Secondly, fit theory proposes that outcomes are most optimal when personal attributes (e.g., needs, abilities, values) and environmental attributes (e.g., supplies, demands, values) are compatible. Thirdly, fit theory claims that discrepancies between personal and environmental attributes (misfits) reduce positive outcomes irrespective of the direction of the discrepancies [34]. The Person-Environment Fit Theory is particularly useful in examining the transition process from training to workplace [36]. Swanson and Fouad [36] argued that the Person-Environment Fit places equal emphasis on the needs of both organisations and individuals. Consequently, both the organisation and individual derive satisfaction from each other through the services rendered. High levels of satisfaction for both parties are an indicator of a good 'fit' between the organisation and individual. Such prevailing situation results in good performance outcomes.

The Social Cognitive Theory was postulated by Bandura in 1986 [37]. It started as the Social Learning Theory (SLT) in the 1960s [37]. The theory posits that learning occurs in a social context with a dynamic and reciprocal interaction of the person, environment, and behaviour. SCT considers the unique way in which individuals acquire and maintain behaviour, while also considering the social environment in which individuals perform the behaviour. The theory 
takes into account a person's past experiences, which factor into whether behavioural action will occur. These past experiences influences reinforcements, expectations, and expectancies, all of which shape whether a person will engage in a specific behaviour and the reasons why a person engages in that behaviour.

The Social Cognitive Theory is framed on the following tenets: Reciprocal Determinism, Behavioural Capability, Observational Learning, Reinforcements, Expectations and Selfefficacy. Reciprocal Determinism refers to the dynamic and reciprocal interaction of person (individual with a set of learned experiences), environment (external social context), and behaviour (responses to stimuli to achieve goals). Behavioural Capability entails a person's actual ability to perform behaviour through essential knowledge and skills. Observational Learning asserts that people can witness and observe behaviour conducted by others, and then reproduce those actions. Reinforcements focus on the internal or external responses to a person's behaviour that affect the likelihood of continuing or discontinuing the behaviour. Expectations relate to the anticipated consequences of a person's behaviour. Then, Self-efficacy concerns the level of a person's confidence in his or her ability to successfully perform behaviour. Social Cognitive Theory examines the interplay between self-efficacy, outcome expectancy and goals, as mediated by other personal and contextual variables [38].

The Person-Environment Fit Theory is relevant in this study as it determines if the preparation provided to student teachers is compatible with the teaching practice experience. Similarly, the Social Cognitive Theory is also relevant as student teachers have to transfer knowledge, skills and experiences gained during the preparation at teacher education to teaching practice in a self-efficacious manner.

\section{METHODOLOGY}

The study was a descriptive-correlational research design. It was a census $(\mathrm{N}=80)$ of student teachers who did teaching practice in the 2015/2016 academic year in the Faculty of Agriculture and Consumer Sciences at the University of Eswatini. A close-ended questionnaire, validated by three experts from the Department of Agricultural Education and Extension and Department of Consumer Sciences was used for data collection. Cronbach's Alpha used to calculate inter-item reliability of the questionnaire revealed that the reliability coefficient was .74; implying that the instrument was $74 \%$ reliable. A six point Likert-type scale was used to measure the variables of the study. The questionnaires were distributed by the researchers to the respondents accompanied by a cover letter. Data were collected during the second and third weeks of March 2016. Questionnaires were further coded for easy follow up, and were delivered and then collected a fortnight later from the respondents. A formal letter from the researchers was written to solicit permission from the respondents to participate in the study. Descriptive statistics and correlational statistics in the Statistical Package for Social Sciences (SPSS) version 20 were used for analysing the data.

\section{RESULTS AND DISCUSSIONS \\ Demographic Characteristics and Background Information}

Table 1 revealed that most of the student teachers were in the age range 21 to 25 years $(n=62$, $77.5 \%)$. Thirty four student teachers (42.3\%) were females. Also, 46 student teachers (57.0\%) did the teaching practice at schools in the rural areas and most of the teaching practice schools were public schools $(n=53,56.2 \%)$. A majority of the student teachers $(n=73,91.3 \%)$ were single. Most of the student teachers started learning Agriculture / Consumer Science at Junior Secondary School. Finally, most of the student teachers were doing Agricultural Education $(\mathrm{n}=50,62.5 \%)$. Similar results that revealed that a majority of student teachers were female, single and had not done teaching practice were reported by Tsikati, Dlamini and Masuku [39]. 
Table 1. Distribution of surveyed respondents according to demographic characteristics

\begin{tabular}{|l|c|c|}
\hline Demographic variables & f & \% \\
\hline Age & 62 & 77.5 \\
\hline $21-25$ years & 17 & 21.3 \\
\hline $26-30$ years & 1 & 1.3 \\
\hline 31 and above & & \\
\hline Sex & 34 & 42.3 \\
\hline Male & 46 & 57.5 \\
\hline Female & & \\
\hline Intern school location & 35 & 43. \\
\hline Urban & 46 & 57.0 \\
\hline Rural & & \\
\hline Type of school & 27 & 33.8 \\
\hline Mission school & 53 & 56.2 \\
\hline Public school & & \\
\hline Marital status & 73 & 91.3 \\
\hline Single & 7 & 8.8 \\
\hline Married & & \\
\hline Beginning to learn agriculture/ consumer science & 22 & 27.5 \\
\hline Primary level & 36 & 45.0 \\
\hline Secondary level & 14 & 17.5 \\
\hline High school level & 8 & 10.0 \\
\hline Tertiary level & & \\
\hline Programme of study & 50 & 37.5 \\
\hline B.Sc. Agriculture Education & 30 & \\
\hline B.Sc. Consumer Science Education & & \\
\hline
\end{tabular}

\section{Student teacher training needs prior to preparation for teaching practice}

Table 2 reveals that the most prominent training needs of the student teachers before the preparation stage at the University were on the following: linking theory and practice $(\mu=4.99)$, $\sigma=.89)$; understanding stages of child development $(\mu=4.96, \sigma=.96)$, effective methods of testing $(\mu=4.91, \sigma=.90)$, subject matter $(\mu=4.86, \sigma=.94)$; use of teaching aids $(\mu=4.85, \sigma=.92)$, developing specific strategies for teaching learners $(\mu=4.84, \sigma=1.20)$; developing strategies for handling student misbehaviour $(\mu=4.80, \sigma=.75)$, effective methods of teaching $(\mu=4.76, \sigma=.98)$; among others. The results reiterate that of Brownell, Ross, Colon and McCallum [12] who indicated that teacher education programmes should assist student teachers plan and connect coursework and field work and use of varied teaching strategies. Similarly, Farrant [7] found that preparing student teacher for teaching practice should include equipping them to select and use appropriate content; and decide on the best method of presentation. Bezzina and Madelinska-Michalak [8] stated that student teachers should be able to prepare lesson plans and manage classrooms. 
Table 2. Student teacher training needs prior to preparation for teaching practice $(\mathrm{N}=80)$

\begin{tabular}{|c|c|c|}
\hline Items & $\mu$ & $\boldsymbol{\sigma}$ \\
\hline Linking theory and practice & 4.99 & .89 \\
\hline Understanding the stages of child development & 4.96 & .96 \\
\hline Effective methods of testing & 4.91 & .90 \\
\hline Subject matter & 4.86 & .94 \\
\hline Use teaching aids & 4.85 & .92 \\
\hline Specific strategies for teaching learners & 4.84 & .58 \\
\hline Strategies for handling student misbehaviour & 4.80 & .75 \\
\hline Effective methods of teaching & 4.76 & .98 \\
\hline Facilitating students learning in small groups & 4.71 & 1.09 \\
\hline Activating student prior knowledge & 4.63 & .80 \\
\hline Use specific techniques for teaching topics in Agriculture / Consumer Sciences & 4.55 & .98 \\
\hline Strategies in setting classroom norms & 4.36 & 1.01 \\
\hline Teaching practical sessions & 3.94 & 1.33 \\
\hline Strategies for teaching students from diverse ethnic backgrounds & 3.88 & .97 \\
\hline Strategies for teaching students from diverse racial backgrounds & 3.83 & 1.35 \\
\hline Overall & 4.55 & .95 \\
\hline
\end{tabular}

\section{Rating scale:}

1 - strongly disagree, 2 = disagree, $3=$ slightly disagree,

4 = slightly agree, $\quad 5$ =agree, $\quad 6=$ strongly agree.

\section{Preparedness of student teachers towards teaching practice}

Table 3 revealed that the student teachers were prepared for teaching practice in the following areas: student discipline $(\mu=5.01, \sigma=4.53)$; setting test questions $(\mu=4.90, \sigma=1.12)$, setting exam questions $(\mu=4.72, \sigma=1.01)$, student assessment practices $(\mu=4.46, \sigma=.74)$; effective use of teaching aids $(\mu=4.46, \sigma=1.25)$; classroom management $(\mu=4.44, \sigma=1.16)$; understanding student behaviour $(\mu=4.36, \sigma=1.21)$; Information and Communication Technology skills for teaching $(\mu=4.10, \sigma=1.24)$; among others. Cubukcu [16] reported that student teachers need to be prepared during micro-teaching on the following areas: connection between the course materials and practical application in real classrooms. Student teachers need to be equipped on subject matter and methods of teaching [7]. Bezzina and Madelinska-Michalak [8] found that student teachers should be capacitated on lesson planning and managing classrooms. Bhargava [6] reported that lesson planning, classroom management, time management and assessment and awarding of marks are the most important areas student teachers should master in teaching practice.

Table 3. Preparedness of student teachers towards teaching practice $(\mathrm{N}=80)$

\begin{tabular}{|l|c|c|}
\hline Item & $\boldsymbol{\mu}$ & $\boldsymbol{\sigma}$ \\
\hline Student discipline & 5.01 & .53 \\
\hline Setting test questions & 4.90 & 1.12 \\
\hline Setting exam questions & 4.72 & 1.01 \\
\hline Student assessment practices & 4.46 & .74 \\
\hline Effective use of teaching aids & 4.46 & 1.25 \\
\hline Classroom management & 4.44 & 1.16 \\
\hline Understanding student behaviour & 4.36 & 1.21 \\
\hline ICT skills for teaching & 4.10 & 1.24 \\
\hline Hands-on activities for teaching scientific concepts & 4.06 & 1.25 \\
\hline Effective use of technology for teaching & 4.06 & 1.37 \\
\hline School management & 3.70 & 1.43 \\
\hline Student counselling & 3.61 & 1.42 \\
\hline Overall & $\mathbf{4 . 5 9}$ & $\mathbf{. 6 1}$ \\
\hline
\end{tabular}




\section{Relationship between student teachers' preparedness and their demographic characteristics}

Table 4 presents results on the relationship between preparedness of student teachers and their demographic characteristics. The results indicate that school location had a positive substantial association with the preparedness of student teachers $(r=.57)$. A negative moderate relationship existed between the student preparedness for teaching practice and the level at which the student learn agriculture for the first time $(r=-.36)$. This suggests that a further study should be conducted to explain these relationships.

Table 4. Relationship between student teachers' preparedness and their demographic characteristics

\begin{tabular}{|l|c|}
\hline Independent variables & r \\
\hline Student teacher preparedness & 1.00 \\
\hline Age & -.14 \\
\hline Sex & .07 \\
\hline School location & .57 \\
\hline Type of school & -.16 \\
\hline Marital status & -.01 \\
\hline Level at which student began learning agriculture/ consumer science & -.36 \\
\hline Programme of study & -.10 \\
\hline
\end{tabular}

\section{CONCLUSIONS}

The study concluded that the training needs student teachers had before they were prepared for teaching practice were met during the preparation stage at the University before they went for teaching practice. Furthermore, the study concluded that the student teachers were prepared for teaching practice and there was congruence between the preparation and the teaching practice. This implies that teacher training institutions must make sure that the training provide in consistent with teaching practice. The results of the study are consistent with the theories that framed the study. The Person-Environment Fit Theory is confirmed by the study as the preparation provided to student teachers is compatible with the teaching practice experience at teaching practice schools. Also, the Social Cognitive Theory is confirmed by the transfer of the knowledge, skills and experiences acquired during the preparation for teaching practice in a self-efficacious manner.

\section{RECOMMENDATIONS}

The University of Eswatini - Faculty of Agriculture and Consumer Science should match the needs of students with those of the teaching practice school during the preparation of the student teachers for teaching practice in order to fortify the training. Since the preparation in this study was mainly on the professional aspect of the student teacher preparation; it is imperative to conduct a similar study to address the technical aspect of the teaching practice exercise. A further study is also essential to consider the congruence between the micro-peer teaching and the teaching practice at the University of Eswatini. 


\section{LITERATURE CITED}

Ronfeldt, M., and Reininger, M. 2012. More or better student teaching? Teaching and Teacher Education 28(8): 1091-1106. doi: 10.1016/j.tate.2012.06.003

Mannathoko, N. 1993. Measures of effective teaching. Retrieved from http://www.gatesfoundation.org

Bill and Melinda Gates Foundation. 2010. Intensive partnerships for effective teaching. Retrieved from http://www.gatesfoundation.org/united-states/Pages/statement-on-intensive- partnerships effective-teaching.

Goethals, M. S., and Howard, R. A. 2000. Student teaching: A process approach to Reflective practice. Upper Saddle River, NJ: Merrill.

Kiggundu, E., and Nayimuli, S. 2009. Teaching practice: a make or break phase for student teachers. South African Journal of Education 29: 345-358.

Bhargava, A. 2009. Teaching Practice for Student Teachers of B.ED Programme: Issues, Predicamental and Suggestions. Turkish Online Journal of Distance Education, 10(2): 1-7.

Farrant, J.S. 1990. Principles and Practice of Education. London: Longman: Greenland Co.

Bezzina, C. and Madelinska-Michalak, J. 2008. Preparing student teachers for teaching practicum. In becoming a teacher. DOI: 10.1007/978-1-4020-8874-2_12.

Christenson, R. and Barney, D. C. 2011. Cooperating teachers' expectations for student teachers during the student teaching experience in Physical Education. Asian Journal of Physical Education and Recreation 17 (2): 6-15

Heeralal, P. J. and Bayaga, A. 2011. Pre-service teachers' experiences of teaching practice: Case of South African University. Social Sciences 28(2): 99-105

Very J. D. 1993. The Self-actualising Educand. Pretoria: University of South Africa.

Brownell, M. T., Ross, D. D., Colon, E. P. and McCallum, C. L. 2005 Critical features of special education teacher preparation: A comparison with general teacher education. The Journal of Special Education 38 (4): 242-252

Haigh, M. 2006. Coherence and Congruence of Perceived Roles within Practicum Partnerships. A Case Study Paper Presented at the New Zealand Association for Research in Education Annual Conference, Christchurch, New Zealand. December 6-9, 2001.

Pamela, L., Grossman. 1990. The making of a teacher: teacher knowledge and teacher education. New York: Teachers college press. Journal of Teacher Education 42 (5): 379-382

Leach, J. 2005. Do new information and communication technologies have a role to play in achieving quality professional development for teachers in the global south? Curriculum Journal, 163: 293-329.

Cubukcu, F. (2010). Congruence and dissonance between micro-teaching and macro- teaching. Procedia Social and Behavioral Sciences, 2, 326-329. Retrieved from www.sciencedirect.com.

Turner, K.., Jones, E., Davies, M. and Ramsay, S. 2004. Student Teacher Perceptions of Preparedness for Teaching. Educating: Weaving Research into Practice, 184-193. Retrieved from https://www.researchgate.net/publication/29453726

Graham, C., and McKenzie, A. 1995. Delivering the promise: the transition from higher education to work. Education and Training 37(1): 4-11.

Goodwin, J., and O'Connor, H. 2003. Entering work in the 1960s: reflections and expectations. Education and Training 45(1): 13-21

Perrone, L., and Vickers, M. H. 2003. Life after graduation as a "very uncomfortable world": An Australian case study. Education and Training 45(2): 69-78

Taylor, M. S. 1988. Effects of college internships on individual participants. Journal of Applied Psychology 73(3): 393-401

Friedman, I. A. 2000. Burnout in teachers: Shattered dreams of impeccable

Tschannen-Moran, M., and Woolfolk Hoy, A. 2001. Teacher efficacy: Capturing an Elusive construct. Teaching and Teacher Education 17: 783-805

Cains, R. A., and Brown, C. R. 1998. Newly qualified teachers: A comparative analysis of The perceptions held by B.Ed. and PGCE-trained primary teachers of the level and frequency of stress experienced during the first year of teaching. Educational Psychology 18(1): 97-110. 
Department of Agricultural Education and Extension. 2018. Teaching Practice Handbook in Agricultural Education. Eswatini, Luyengo, University of Eswatini - Department of Agricultural Education and Extension

Tsikati, A. F. and Nxumalo, M. 2018. Factors contributing to effective student teacher supervision in the Faculty of Agriculture and Consumer Sciences. 17th BOLESWANA International Education Research Symposium, Windhoek, Namibia, 10-12 July 2018, pp. 296-299.

Malabe, B. 2009. Supervision experience by Agricultural Education student teachers from cooperating teacher. Unpublished bachelor's thesis, University of Swaziland, Luyengo, Swaziland

Nxumalo, P. N. 2015. Agricultural Education and Consumer Science education student teachers' experiences during teaching practice in Swaziland. Unpublished bachelor's thesis, University of Swaziland, Luyengo, Swaziland.

Dlamini, N. 2016. Experiences of cooperating teachers during teaching practice Supervision in Swaziland. Unpublished bachelor's thesis, University of Swaziland, Luyengo, Swaziland.

Lushaba, N. S. 2014. Challenges faced by consumer science education student-teachers during teaching practice in Swaziland. Unpublished bachelor's thesis, University of Swaziland, Luyengo, Swaziland.

Mamba, L. P. 2015. Challenges faced by student teachers during teaching practice from Uniswa Luyengo. Unpublished bachelor's thesis, University of Swaziland, Luyengo, Swaziland.

Mamba, L. T. 2012. Effectiveness of teaching practice on the performance of teachers in the Manzini. Luyengo. Unpublished bachelor's thesis, University of Swaziland, Luyengo, Swaziland.

Holland, J. L. 1985. Making Vocational Choices: A Theory of Vocational Personalities and Work Environments. Englewood Cliffs, NJ: Prentice Hall

van Vianen, A. E. M. 2018. Person-Environment Fit: A review of its basic tenets. Annual Review of Organizational Psychology and Organizational Behavior 5: 75-101. Retrieved from orgpsych.annualreviews.org. https://doi.org/10.1146/annurev-orgpsych-032117-104702

Schneider B. 1987. The people make the place. Personal Psychology 40: 437-53

Swanson, J. L., and Fouad, N. A. 1999. Applying theories of person-environment fit to the transition from school to work. The Career Development Quarterly 47(4): 337-347.

Bandura, A. 1986). Social foundation s of thought and action: A Social Cognitive Theory. Englewood Cliffs, NJ: Prentice- Hall, Inc.

Lent, R. W., and Hackett, G. 1987. Career self-efficacy: Empirical status and future directions. Journal of Vocational Behaviour 30: 347-382

Tsikati, A. F., Dlamini, B. M. \& Masuku, B. M. (2016). Factors influencing the choice an Agriculture speciliasation by Primary teachers diploma college students Swaziland. Journal of agricultural Studies 4(1): 12-24. 